\title{
Blue Economy threats, contradictions and resistances seen from South Africa
}

\author{
Patrick Bond ${ }^{1}$ \\ University of the Witwatersrand, South Africa
}

\begin{abstract}
South Africa hosts Africa's most advanced form of the new Blue Economy, named Operation Phakisa: Oceans. In 2014, the McKinsey-designed project was formally launched by now-disgraced President Jacob Zuma with vibrant state and corporate fanfare. Financially, its most important elements were anticipated to come from corporations promoting shipping investments and port infrastructure, a new generation of offshore oil and gas extraction projects and seabed mining. However, these already conflict with underlying capitalist crisis tendencies associated with overaccumulation (overcapacity), globalization and financialization, as they played out through uneven development, commodity price volatility and excessive extraction of resources. Together this metabolic intensification of capital-nature relations can be witnessed when South Africa recently faced the Blue Economy's ecological contradictions: celebrating a massive offshore gas discovery at the same time as awareness rises about extreme coastal weather events, ocean warming and acidification (with profound threats to fast-bleaching coral reefs), sea-level rise, debilitating drought in Africa's main seaside tourist city (Cape Town), and plastic infestation of water bodies, the shoreline and vulnerable marine life. Critics of the capitalist ocean have demanded a greater state commitment to Marine Protected Areas, support for sustainable subsistence fishing and eco-tourism. But they are losing, and so more powerful resistance is needed, focusing on shifting towards post-fossil energy and transport infrastructure, agriculture and spatial planning. Given how climate change has become devastating to vulnerable coastlines - such as central Mozambique's, victim of two of the Southern Hemisphere's most intense cyclones in March-April 2019 - it is essential to better link ocean defence mechanisms to climate activism: global youth Climate Strikes and the direct action approach adopted by the likes of Dakota Access Pipe Line resistance in the US, Extinction Rebellion in Britain, and Ende Gelände in Germany. Today, as the limits to capital's crisis-displacement tactics are becoming more evident, it is the interplay of these top-down and bottom-up processes that will shape the future Blue Economy narrative, giving it either renewed legitimacy, or the kind of illegitimacy already experienced in so much South African resourcecentric capitalism.
\end{abstract}

Keywords: Blue Economy, capitalist crisis, Oceans Phakisa, resistance, South Africa

\section{Résumé}

L'Afrique du Sud abrite la forme la plus avancée de la nouvelle économie bleue, baptisée «Opération Phakisa: Océans». En 2014, le projet conçu par McKinsey a été officiellement lancé par le président aujourd'hui déshérité, Jacob Zuma, avec un fanfare de la part de l'État et des entreprises. Sur le plan financier, les éléments les plus importants devraient provenir d'industries promouvant les investissements maritimes et les infrastructures portuaires, une nouvelle génération de projets d'extraction de pétrole et de gaz en mer et l'exploitation minière des fonds marins. Cependant, ceux-ci entrent déjà en conflit avec les tendances sousjacentes de la crise capitaliste associées à la suraccumulation (surcapacité), à la mondialisation et à la financiarisation, en raison d'un développement inégal, de la volatilité des prix des produits de base et d'une extraction excessive des ressources. L'ensemble de cette intensification métabolique des relations entre la nature et le capital est manifeste lorsque l'Afrique du Sud a récemment fait face aux contradictions écologiques de l'économie bleue: célébrer la découverte massive de gaz offshore tout en sensibilisant l'opinion publique

\footnotetext{
${ }^{1}$ Patrick Bond, Distinguished Professor of Political Economy, University of the Witwatersrand, Johannesburg, South Africa. Email: patrick.bond "at" wits.ac.za. Thankyou to the JPE Special Section editors and reviewers. This is the first article in John Childs and Christina Hicks (eds.). 2019. "Political ecologies of the blue economy in Africa", Special Section of the Journal of Political Ecology 26: 323-465.
} 
aux phénomènes météorologiques extrêmes sur les côtes, au réchauffement des océans et à l'acidification conduisant à blanchiment des récifs coralliens, élévation du niveau de la mer, sécheresse débilitante dans la principale ville touristique balnéaire d'Afrique (Cape Town) et infestation plastique des plans d'eau, du littoral et de la vie marine vulnérable. Les critiques de l'océan capitaliste ont réclamé un plus grand engagement de la part de l'État en faveur des aires marines protégées, un soutien à la pêche de subsistance durable et à l'écotourisme. Mais ils sont en train de perdre et une résistance plus puissante est donc nécessaire, en se concentrant sur le passage aux infrastructures d'énergie et de transport post-fossiles, à l'agriculture et à l'aménagement du territoire. Le changement climatique est devenu dévastateur pour les côtes vulnérables comme le centre du Mozambique, victime de deux des cyclones les plus intenses de l'hémisphère sud en marsavril 2019 - il est donc essentiel de mieux relier les mécanismes de défense des océans à l'activisme climatique: L'approche d'action directe adoptée par des groupes comme Dakota Access Pipe Line, aux États-Unis, Extinction Rebellion en Grande-Bretagne et Ende Gelände en Allemagne. Aujourd'hui, alors que les limites des tactiques de déplacement de crise des capitaux deviennent de plus en plus évidentes, c'est l'interaction de ces processus globaux et de la base qui façonnera le récit futur de l'économie bleue. Il retrouvera soit une légitimité renouvelée, soit le type d'illégitimité déjà ressenti dans un tel capitalisme centré sur les ressources en Afrique du Sud.

Mots-clés: économie bleue, crise capitaliste, Océans Phakisa, résistance, Afrique du Sud

\section{Resumen}

Sudáfrica alberga la más avanzada forma de economía azul, llamada "Operación Phakisa: Océanos." En 2014, el proyecto diseñado por McKinsey, fue lanzado formalmente con ánimo y fanfarria estatal y corporativa por el ahora desacreditado presidente Jacob Zuma. Se adelantó que las principales contribuciones financieras provendrían de corporaciones promotoras de la inversión en transporte marítimo e infraestructura portuaria, una nueva generación de proyectos de extracción marítima de petróleo y gas, así como de explotación minera de fondos marinos. Sin embargo, esto crea conflicto con tendencias de crisis capitalistas subyacentes asociadas con sobreacumulación (sobrecapacidad), globalización, financiarización, y el papel que tuvieron en el desarrollo desigual, la volatilidad del precio de mercancías y la excesiva extracción de recursos. Al mismo tiempo, esta intensificación metabólica de las relaciones con origen en el capital, pudieron ser presenciadas recientemente cuando Sudáfrica enfrentó las contradicciones ecológicas de la economía azul: celebrando un enorme descubrimiento de gas, cuando al mismo tiempo urge la conciencia de eventos climáticos costeros extremos, calentamiento y acidificación del oceáno (con severas amenazas al rápido blanqueamiento de los arrecifes de coral), el aumento del nivel del mar, la desgastante sequía en la principal ciudad turística costera de África, así como de la infestación de plásticos en cuerpos de agua, el litoral y la vulnerable vida marina. Los críticos del océano capitalista han demandado un mayor compromiso del estado con las áreas marinas protegidas, respaldo a la pesca sustentable y al ecoturismo. Sin embargo, van perdiendo, por lo que requieren una resistencia más poderosa enfocada en energía post-fósil e infraestructura de transporte, agricultura y ordenación territorial. Dado que el cambio climático ha sido devastador en litorales vulnerables - tal como Mozambique central, víctima del tercer ciclón más intenso en el Hemisferio Sur, en marzo del 2019 -, es esencial mejorar el vínculo entre los mecanismos de defensa del océano y el activismo climático: el Golpe Climático Juvenil (Youth Climate Strikes) a nivel global, y el enfoque de acción directa adoptado por la gente de la resistencia al oleoducto de Dakota, en Estados Unidos, Rebelión contra la Extinción en la Gran Bretaña y Ende, en Alemania. Hoy, como la globalización, financiarización y la acumulación por desposesión alcanzan límites funcionales como una estrategia de la crisis del desplazamiento del capital, es en la interacción de estos procesos de arriba hacia abajo y de abajo hacia arriba, que en años que vienen la narrativa de la economía azul adquirirá forma, dando, ya sea una legitimidad renovada, o el tipo de ilegitimidad que se ha experimentado en el capitalismo africano centrado en recursos.

Palabras clave: economía azul, crisis capitalista, Oceans Phakisa, resistencia, Sudáfrica

\section{Introduction}

Although not yet fully established in the scholarly literature, the term 'Blue Economy' is becoming ubiquitous for countries with extensive coastlines. The narrative has roots in global public policy, such as the United Nations (2012) Rio+20 conference, which defined the Blue Economy as "marine-based economic development that leads to improved human wellbeing and social equity, while significantly reducing 
environmental risks and ecological scarcities." Kathijotes (2013: 8) links this to "the new system of oceanbased Green Economy that interweaves creative neo-science and technologies with the ocean", generating "a new growth engine by promoting both the sustainable use and preservation of the oceans, ensuring the Earth's continued survival." In 2018, 18,000 delegates attended a Sustainable Blue Economy Conference in Nairobi that generated 62 'commitments' in ten categories: marine protection; plastics and waste management; maritime safety and security; fisheries development; financing; infrastructure; biodiversity and climate change; technical assistance and capacity building; private sector support; and partnerships (Wagner 2018).

In their seminal critique, Silver et al. (2015: 136) assert that the Blue Economy encompasses both environmental fears, and corporate and state desires for economic and geopolitical expansion: "catalysts include ocean acidification and sea-level rise, overfishing and marine biodiversity loss, a growing consensus regarding the conservation and development potential of the high seas, and, interest from some countries in territorializing more ocean space." Kerr et al. (2018: 34-35) sum up what is wrong with this process:

States claim sovereign jurisdiction over their coastal waters, and private ownership of marine spaces remains rare. In many places, the sea is considered a commons, public good, or free for all to use, and legal regimes generally reflect this. The perception of the marine environment as being a 'public good' is even stronger in cultures or communities with close connections to the sea, precisely the communities that are seeing new industries develop on their shore. As the Blue Economy grows and seeks new capital opportunities, what was once considered a commons is being enclosed.

Researchers either confirm or condemn ocean commodification. One South African scientist seeks "measurable and calculable terms" for the Blue Economy, so that "standards may be set for it, allowing for a systems approach in how it balances regime-related obligations with socio-economic activities, without ecological degradation of the oceans" (Smith-Godfrey 2016: 63). Spalding (2016: 2) cites a US\$3-6 trillion range for ocean-related GDP, acknowledging "the need for an economy classification specifically related to the ocean and its myriad of goods and services." Burgess et al. (2018: 331) provide several managerialist rules regulating "diverse ocean uses - such as fisheries, shipping, and tourism - and marine ecosystem services such as food provisioning, coastal protection, and carbon storage - are interconnected, and additional value can be gained from managing these uses and services jointly rather than managing them separately."

Thus the terrain of debate is characterized by self-interest masked by a posture of more general socioecological concern. As Blythe et al. (2018: 1213) argue, "policy makers can distort the language of transformation to define acceptable formulation of problems and solutions to those problems that serve to reproduce existing structures of power and domination and justify business as usual." Like much Sustainable Development Goal framing, soaring rhetoric and technological sophistication disguise the darker side of the Blue Economy concept: its coincidence with a drive towards ever-deeper and destructive undersea oil and gas drilling and mineral extraction; the shipping industry's concentration and centralization; an upsurge of eliteoriented marine and coastal tourism; corporate corruption of weak states; and the use of unsustainable shoalidentification radar technology by large-scale commercial fishing capital. Africa's coastlines reflect the increasingly carbon- and plastic-saturated character of oceans, pressure which gives local and global capitalism the opportunity to impose dangerous new accumulation strategies. So while the reduction of environmental risk and scarcity ultimately requires a regulated ocean, one managed with eco-socialist principles as a genuine commons, the current process is one of corporate expansion into the ocean, where externalities appear beyond the political will of national and global regulation (especially in the case study country, South Africa).

Perhaps most vitally, the seas are one of nature's main forms of sequestering carbon dioxide, although less so as saturation points are reached. As Johnson et al. (2018: 1) point out, "the potential denudation of these carbon-removing processes has potential to significantly hamper the effort to reduce atmospheric $\mathrm{CO}_{2}$ in order to keep within the 1.5 degrees of warming." $\mathrm{CO}_{2}$ emissions and other forms of pollution have in recent years generated dangerous levels of acidification, rising temperatures and hence more intense hurricanes and typhoons (including Southern Africa's two worst-ever cyclones in March-April 2019), coral reef bleaching, 
and loss of marine micro species. Dumping or leaching of plastics and other pollutants that make their way to the ocean are so prolific they threaten many species' reproduction and the marine food chain. And as ultraviolet rays fragment secondary plastics - such as water bottles - into microbial pieces of less than five millimeters, they are then ingested by zooplankton and the fish that are responsible for a fifth of the global population's protein consumption. As oceans become increasingly stressed as a result, their economic benefit in the form of fishing and tourism will fade, to be replaced by ever more extreme forms of fossil fuel extraction and underwater mining, alongside periodic advances in ocean-derived biotechnology, aquaculture, pharmaceutical products and algal biofuels.

Blame for this process can and should be - though very rarely is - attributed to an extractivist, hyperspeculative, debt-driven, mercantilist, eco-externality-riddled and climate-chaotic economy now on the verge of a major crisis of overaccumulated capital. One recent symptom, starting well before the 2016 Brexit vote and Donald Trump's presidency, is 'deglobalization.' The word describes the process of shrinking rates of capital and trade flows, not unlike prior episodes in the 1880s and 1930s (Garcia and Bond 2018). The most obvious contradictions of overaccumulation and spatial fix are witnessed in the post-2008 collapse of the Baltic Dry Index (measuring the cost of international container shipping), accompanied by a new, untenable wave of mega-ship construction. The McKinsey Globalization Institute (2019: 8) admits that "a smaller share of the goods rolling off the world's assembly lines is now traded across borders. Between 2007 and 2017, exports declined from 28.1 to 22.5 percent of gross output in goods-producing value chains."

However, the academic literature is thus far innocent of these trends, and is apparently unprepared to confront the Blue Economy as a futile albeit extremely damaging exercise in displacing the overaccumulation crisis in the era of deglobalization. A literature review by Winder and Le Heron (2017) in Dialogues in Human Geography covering "globalizing biological-economic relations in multi-use marine environments", does not mention either capital flows or social resistance. ${ }^{2}$ The most cited use of the term Blue Economy is in a book by Gunter Pauli (2010) focused less on ocean-based accumulation and instead mainly committed to biomimicry and circular sustainability logics. Its use in scholarship since 2012 mainly reflects the commodification process that Silver et al. (2015) warned of: "oceans as natural capital and oceans as good business" (later, we will consider why, if natural capital accounting were actually to be taken seriously, policymakers would insist upon a dramatic reduction in non-renewable resource extraction, including sea-bed minerals and offshore oil and gas). The Blue Economy is mainly based upon ecological-modernization assumptions (Eikeset et al. 2018). This reflects, as Mads Barbesgaard (2018: 130) points out, the influence of the "World Wide Fund for Nature and Conservation International, the financial sector including Credit Suisse and Goldman Sachs, and even military companies like Lockheed Martin." The codification of their ideas are most obvious in the World Bank's 2016 US\$6.4 billion Blue Growth Portfolio and the European Commission's (2014) Blue Growth Strategy.

Hadjimichael (2018: 161) explores the latter strategy's "disavowal of the limits to blue growth," especially overfishing and sea bed mining. Other political-ecological critiques of the Blue Economy include those concerned with distributive justice in fisheries (Bavinck et al. 2018), and with marine protected areas, marine spatial planning initiatives and global ocean governance (Bennett 2018). However, eco-modernization perspectives appear dominant, e.g. in mitigating micro-ecological damages stemming from agricultural pesticide and fertilizer run-off, municipal wastewater and storm water, and management of other pollution and nutrient crises (Kathijotes 2013). Specific cases subject to such studies include South Asian countries Bangladesh (World Bank 2018a), India, Pakistan, the Maldives and Sri Lanka (Sakhuja 2015) - and the East Asian Seas (Ebarvia 2016).

In contrast, critical scholarship on the Blue Economy is aimed at deconstructing narratives, assessing public policy, and identifying local case studies associated with the ocean's ecological modernization. The rest of this article contributes a new terrain of Blue Economy argumentation, based on self-destructive materialist processes from global to local scales, and social resistance. The first concern draws attention to the metabolism of global capital accumulation, given that the recent appropriation of maritime nature is mediated by the limits

\footnotetext{
2 There are exceptions, e.g. when Bavincka et al (2018: 47) claim that "current academic debates on fisheries are largely myopic" because they ignore fisherfolk struggles although "addressing social justice concerns may be a precondition for achieving sustainable human-nature relations."
} 
of overproduction, including deglobalization and the restructuring of the shipping industry. The next section describes South Africa's - and specifically the Durban port's - insertion in the global mercantile and fossil-fuel circuitries of capital, at a time when Blue Economy rhetoric is masking socio-ecological destruction through Operation Phakisa: Oceans. The subsequent section addresses specific aspects of climate change associated with South Africa's distorted Blue Economy politics, and the final section considers resistance politics.

\section{Overproduction, financialization, deglobalization and the Blue Economy}

One driving force behind corporate ocean-grabbing is the need to 'spatially fix' a generalized problem of overaccumulated capital (Harvey 1982). This is not a specific case reducible to any particular economic sector, because financialized capital is the site at which the general flows of capital converge, and where the impetus is strongest in the search for new temporal, geographical and environmental outlets for accumulation (Bracking 2015). At root is capital's organic composition (ratio of machines to workers), which rises due to the inexorable pressure to become more productive. At that stage, capitalism exhibits a tendency towards overproduction (gluts of output, as well as labor and machinery). What happens next is revealing.

The rate of profit tends to decline so capital then begins 'shifting', in what is known as the spatial fix: the territorial expansion of corporate reach, so as to identify new markets and less expensive sources of labor and raw materials (including lower regulatory and tax burdens). Next comes a different, sectoral move: away from reinvestment of producers' profits into new plant and equipment, and instead into more speculative activities within the financial circuit of capital, including debt instruments that allow consumption now and payment later. That process we can term 'stalling' the crisis, although it is also known as the 'hollowing' of corporations. Finally comes outright 'stealing,' or 'accumulation by dispossession' (to borrow terms introduced by Harvey 1982, 2003). This mix of shifting, stalling and stealing includes a turn seawards, in search of renewed profitability akin to 'land-grabbing' of poor countries' better soils and resources. That phenomenon was understood as mainly based on agriculture, mining and petroleum extraction purposes during the commodity super-cycle. ${ }^{3}$

Today, long after the demise of commodity speculation, the problem of overaccumulated capital at the global scale appears mainly to be emanating from two sources: real economy overproduction especially driven from China, and financial economy over-indebtedness and speculation, found in nearly all the world's stock and credit markets. The latter may be the most important barrier, ultimately, to arranging the levels of financing required for ocean-related infrastructure development, including new ports. The global debt markets soared from US $\$ 200$ trillion in 2011 to nearly US $\$ 250$ trillion by 2018 (a rise from 300 to 320 percent of world GDP). Not only did Wall Street continue to hit unprecedented highs (prior to a late 2018 correction), so too did stock markets bubble up to untenable levels, including within the Brazil-Russia-India-China-South Africa (BRICS) bloc: South Africa reaching a 2018 level of share value to GDP that was 90 percent higher than in 2010, India 70 percent higher and Russia 50 percent higher. China's stock exchanges were in the same league. However, just as the yuan was made an IMF-acceptable global currency reserve in 2015, the mainland Chinese markets lost more than US $\$ 5$ trillion in two share bubble bursts. Stabilizing these markets required intense reregulation of capital markets and other investment controls, an omen for the rest of the world, especially given that the Trump tax cuts of 2017 did not translate into higher levels of fixed investment but instead, corporate stock buybacks and share price inflation.

The underlying problem, the IMF recorded (2017: 18), was China's productive-sector overcapacity: more than 30 percent in coal, non-ferrous metals, cement and chemicals by 2015 (and in each, China is responsible for 45-60 percent of world production). In attempting to displace this capital, Chinese outward Foreign Direct Investment (FDI) rose by 21 percent in 2016 to US\$2.1 trillion (UNCTAD 2017: 18). China had by then become a net outward direct investor and indeed the second largest global investor (after the US), accounting for US\$183 billion in Chinese FDI. As the UN Conference on Trade and Development put it,

\footnotetext{
${ }^{3}$ The 2008 and 2011 peaks of the commodity super-cycle were followed by subsequent price crashes: e.g., coal from US\$170 to US\$60/ton in 2008, up to US\$120 in 2011 and down to US\$50/ton in 2016 before reviving to US\$100 in 2019 - and oil to US\$145/barrel in 2008, down to US\$45, then up to US\$110 from 2011-2014, before falling as low as US\$26 in 2016 before rising to US\$70 in 2019.
} 
"Chinese multinational enterprises invested abroad to gain access to new markets and to acquire assets that generated revenue streams in foreign currency" (UNCTAD 2017: 14).

However, while OBOR presented opportunities for the Chinese 'Going Out' strategy, the rest of the world began suffering deglobalization, partly witnessed declining rates of foreign profits and the consolidation of FDI, according to UNCTAD (2018). Well before Trump's trade wars had an impact (although at a time his tax cuts pulled US capital homewards), the 2017 absolute volume of global FDI declined 23 percent, to US\$1.43 trillion (UNCTAD 2018: 1), and further in 2018 to US\$1.20 trillion. New annual FDI had peaked at 5.3 percent of world GDP in 2007, and fell to just 1.5 percent in 2018, due, according to UNCTAD, falling profits: "A decrease in rates of return is a key contributor to the investment downturn. The global average return on foreign investment is now at 6.7 percent, down from 8.1 percent in 2012. Return on investment is in decline across all regions, with the sharpest drops in Africa" (UNCTAD 2018: xii). UNCTAD (2019: 1) reiterated in 2019, "The factors behind this negative trend, such as lower profitability of foreign investment and shifts in global value chains, are not changing in the near future." In short, excessive production and the resulting drive to financialization revealed a dilemma long associated with the uneven spatial ebb and flow of capital: geographic expansion was first an opportunity, but then a constraint to profitability.

Indeed rates of trade/GDP, which as the most obvious measure of globalization had peaked at 61 percent in 2012, fell steadily to 56 percent in 2017. ${ }^{4}$ As McKinsey Globalization Institute (2019: 8) shows, exports as a share of manufactured goods output rose from 8 percent in 1995 to 18 percent in 2007 and fell to 10 percent in 2017, while other countries termed 'developing' had a 4.4 percent fall from 2007 peaks. Reflecting the dramatic compression of manufacturing trade since then, the Baltic Dry Index crashed more than 90 percent within six months in 2008, from a level of nearly 12,000. After a slight rebound, he Index fell further, to below 300 by early 2016 (Figure 1).

Vast shipping overcapacity came on line, forcing the 2016 scrapping of more than 1,400 dry bulk ships, 15 percent of the world fleet. The Index subsequently rose back above the 1000 level but in 2019, new capacity continued to threaten industry upheaval, especially involuntary mergers and acquisitions. 'Post-Panamax' ships - carrying more than 5,000 twenty-foot equivalent unit ('TEU') containers (until 2015, the limits of the size that fit through the Panama Canal) - began to dominate world shipping, to the point that vessels with more than 10,000 TEUs were flooding the market. Such highly-robotized ships carried only 13 crew. As these processes unfolded, Africa stood increasingly exposed, for the continent's ports (including Durban) mostly suffer from shallow berths. ${ }^{5}$

There is no hope of a decisive upturn, despite the hype surrounding China's 'One Belt One Road' (OBOR) mega-infrastructure projects. OBOR is touted for restoring some market demand for constructionrelated commodities. However, at a deeper structural level, China suffers from the apparent exhaustion of prior sources of profitability: "an expanding external market, a relatively large reserve army of labor, and a low debtincome ratio," according to Hao Qi (2017). The prior (2009-2012) expansion of massive urban infrastructure and housing construction was also soon exhausted, leaving exposed the Chinese phenomenon known as Ghost Cities. The OBOR appears as a potential multi-trillion dollar mirage, and one that may in the process even crack the BRICS, in the event the Kashmir OBOR routing continues to cause alienation between Xi Jinping and Narendra Modi (Garcia and Bond 2018). Xin Zhang (2016) explains that "although there is an element of

\footnotetext{
${ }^{4}$ Here, the BRICS suffered faster declines in relative trade than the world as a whole. Russia peaked first at a 69 percent trade/GDP ratio in 1999, and then fell steadily to 47 percent by 2017. Brazil peaked at 30 percent in 2004 and fell to 28 percent in 2017. China peaked at 66 percent in 2006 and plummeted to 34 percent. South Africa peaked in 2008 with 73 percent and is now 58 percent, and India peaked last, in 2012 with 56 percent, and is now down to 41 percent (Garcia and Bond 2018; World Bank 2018b).

${ }^{5}$ These relatively shallow ports include Durban as well as South Africa's next three main container-oriented port cities: Cape Town, Port Elizabeth and East London. The country only has three deep-water ports that can potentially handle the newer Supramax and Capesize ships (some now carrying 21,000 containers, with 24,000-size ships imminent): Richards Bay (mainly bulk mineral exports), Coega and Saldanha, all of which are far from the major markets (Pieterse et al. 2016). The shake-out of excess capacity ahead will invariably be uneven, and create havoc for massive port construction projects that Chinese state capital had promoted along its Maritime Silk Road. Globally, fifty ports have annual container throughput of more than a million twenty-foot equivalent units, many of which are on the Chinese coast.
} 
US-China competition for global hegemony behind the OBOR, the main driving force is the pressure from overaccumulation in a typical capitalist economy when it approaches the end of a major cycle of capitalist cyclic change." As a result, "there is also an ongoing debate about whether it is economically rational to pour such huge amounts of money into low-return projects and high-risk countries, especially in the case of massive infrastructural projects" (Zhang 2016).

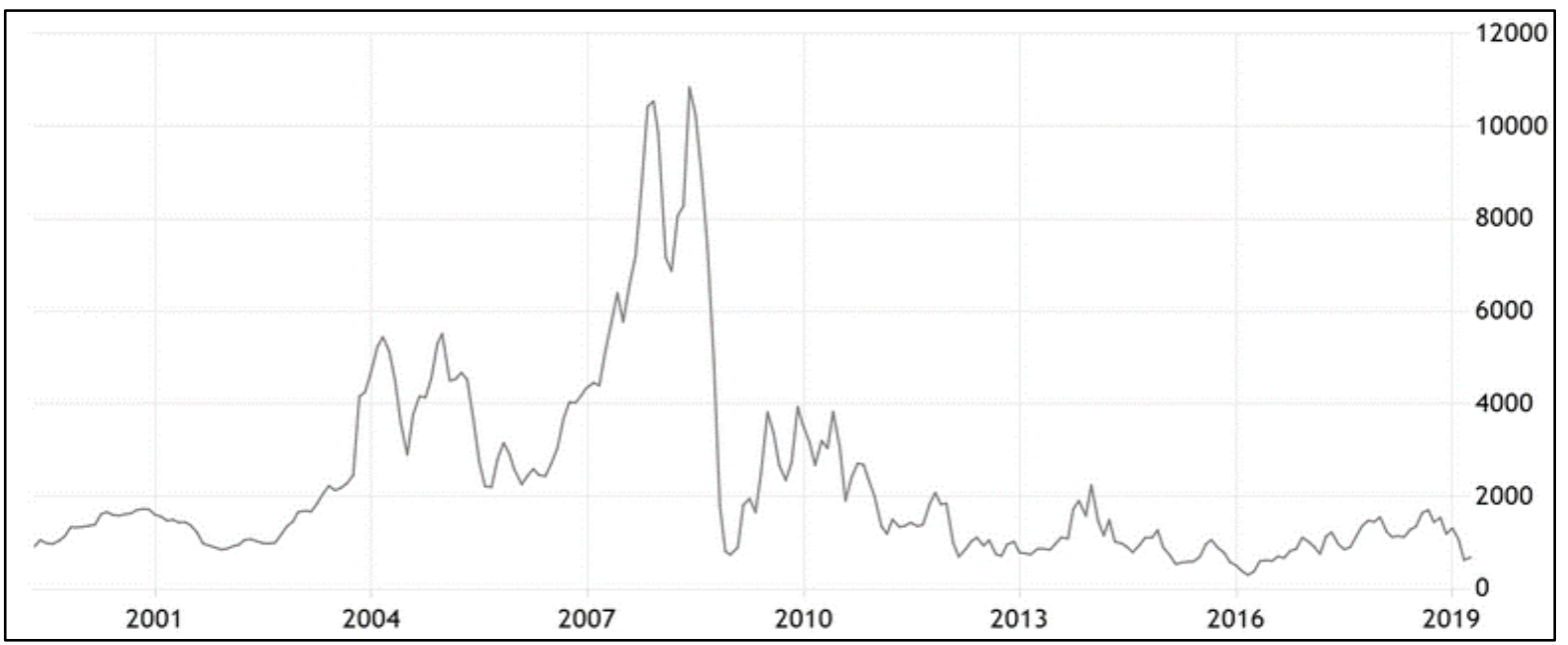

Figure 1: Baltic Dry Index, 2002-2019. Source: TradingEconomics.com

Again, what had seemed an opportunity was now a constraint. A major Sri Lankan port near Colombo that suffered Chinese foreclosure is the main example, but there are similarly stressed East African marine transport links to OBOR. These include the furthest-north African port in OBOR, in Djibouti, where Ethiopian sweat-shop manufacturing (also Chinese-financed) can now be exported directly via a US\$4 billion railroad from Addis Ababa. Similarly, Djibouti's state port may also be appropriated by the Chinese. Kenya's US\$5 billion Lamu port construction (mostly Chinese financed) now underway not far from the Somalia border, is replete with security, environmental, land-grabbing and financial concerns. ${ }^{6}$ A bit further south, a US\$3.2 billion Nairobi-Mombasa rail line was built by China during the 2010s, but soon dramatically raised both Kenya's public debt and foreign debt, to the point that in 2018, a potential collateral takeover of the Mombasa port by Chinese firms was rumoured. A US\$3.6 billion Uganda-Tanzania oil pipeline is planned to facilitate oil exports via Dar es Salaam.

Also in Tanzania in October 2017, China's main port builder - China Merchants Holdings International - took over project ownership and financing responsibility for the US\$12 billion Bagamoyo port and Industrial Development Zone, once the Tanzanian president had pulled back on his predecessor's support due to austerity (Kangethe 2017). Once complete, the port will handle ten times more containers than nearby Dar es Salaam harbor, allegedly becoming Africa's largest (Shepard 2017). Similar rail lines from ports to mines are planned, along with refurbishment of the Chinese TanZam line to Lusaka, dating back a half-century. In Mozambique, there are major Chinese and Indian investments in Maputo and Beira (the latter mainly for coal exports), although the durability of the latter was thrown into doubt by Cyclone Idai's March 2019 destruction of much of that city's infrastructure. South Africa has witnessed growing Chinese port and rail investments in Richards Bay and Durban (both coal-export harbors), again with a tragic irony insofar as the latter city sustained massive damage mainly in the neighborhoods just south of the port (including 65 deaths) during the April 2019 Easter

\footnotetext{
${ }^{6}$ The rail line will ostensibly link to South Sudan's oil fields, but between civil war there and Al-Shabaab's attacks on Kenya, the project is extremely risky. Indeed 2017 also witnessed widespread community protest by the groups Save Lamu, Cordio East Africa and Muslims for Human Rights. Their targets included a US\$2 billion coal fired power plant, on grounds of local ecological damage and climate change (Business Daily Africa 2017).
} 
weekend. On Africa's Atlantic Coast, there are another ten major port expansions, though their economic sustainability remains questionable.

Mega-projects that follow from such capital export - whether BRICS or Western in origin - are especially vulnerable to such overinvestment and then cancellation. In South Africa, major export processing zones with ocean access - such as at the Coega and East London Special Economic Zones (Thompson, Tsolekile de Wet and Awaseh 2018) - have become white elephant investments, drawing billions of dollars of state subsidies since the early 2000s with substantial ongoing losses. In addition, maritime and logistics megaprojects have been subject to high levels of corporate corruption. This is amply evident in the main South African location for Blue Economy hype, the port of Durban.

\section{Durban's port-petrochemical complex as South Africa's Blue Economy guinea pig}

Within Africa, a profound dispute over expansion of ocean-based investment is occurring in South Durban, partly due to nearby offshore deep-water oil and gas exploration by several of the world's largest oil companies, to potentially take advantage of a refinery complex. Moreover, port expansion and the prospect of a brand new port (on the city's former airport runway) also loom large in political economy and political ecology conflicts (Figure 2).

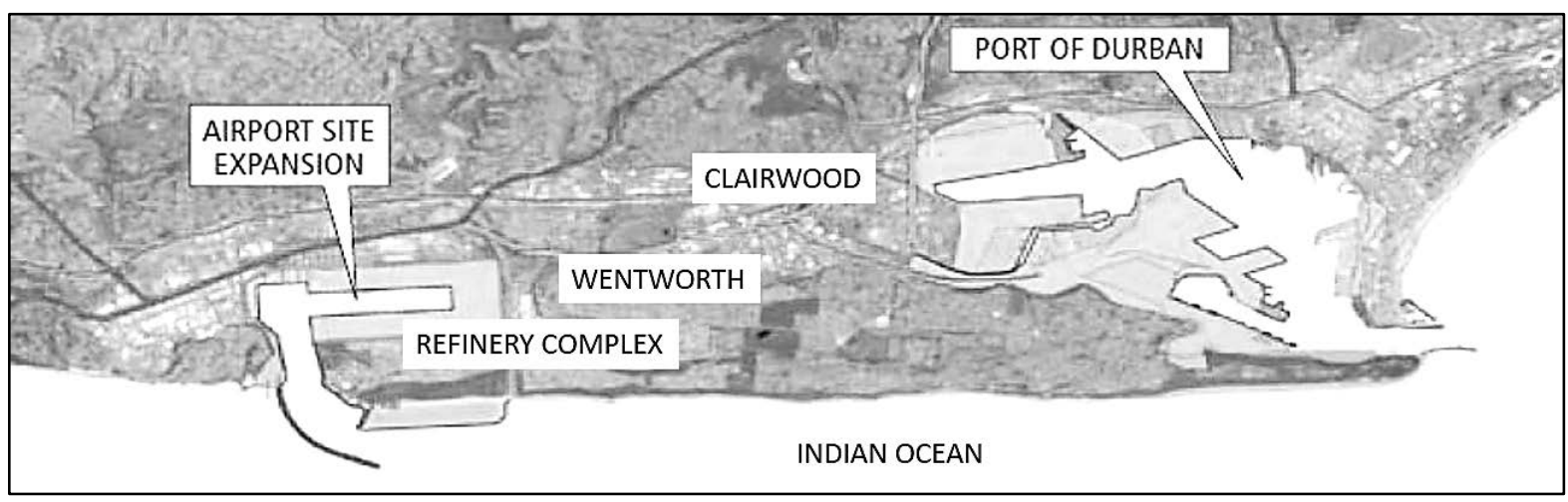

Figure 2: South Durban port-petrochemical complex expansion plans, 2008-2040. Source: Transnet.

South Durban has already suffered from the impacts of unplanned container growth and the demise of rail-based transport in favour of trucking, with devastating implications for displacement of long-time black residents in the increasingly logistics-centred neighbourhood of Clairwood, bordering the port (Bond 2017). The main residential area next to the proposed new port, Wentworth, is already notorious for public health and safety hazards, given that it hosts the largest oil refinery complex in Africa. Nevertheless, Transnet built new oil piping doubling the capacity for transfer from Durban to Johannesburg - spending four times more than the US\$500 million budgeted to do so from 2006-2016 - and from 2008, began preparing the existing harbor for a new wave of massive ships, even though annual TEU container volumes had held steady at less than 2.7 million units for many years. Then in 2017, extensive Transnet corruption was revealed involving two Chinese suppliers of container-lifting cranes (Shanghai Zhenhua Heavy Industries) and locomotives (South China Rail), funded through what was in 2013 advertised as a US\$5 billion credit from the China Development Bank. In mid-2018, just as Transnet's chief executive was losing his job for corruption related to procurement contracts (entailing massive theft by the infamous Gupta brothers from India), the parastatal borrowed US\$200 million from the BRICS New Development Bank for further port expansion. However, by November 2018, that project was also derailed by corruption, this time involving an Italian construction company and Durban's most notorious family for committing serial patronage fraud (Bond 2019).

Still, these projects continue apace in official development rhetoric. The seductive character of massive ocean-based trade and investment was on display at Durban's oldest local country club on November 10, 2016. 
The lines of argument made by the host were identical to those trotted out mindlessly in similar settings: investor-seeking port cities across the African continent and world. China's OBOR map ends in East Africa, but the specter of massive new Beijing-subsidized port construction up and down the Indian and Atlantic Oceans petrifies Durban's elites, fearful of losing out - and not shy about using these threats to serve their own interests. Repeated events of this sort in port cities suggest an excessive commitment to what David Harvey (1989) terms "interurban entrepreneurial competition."

At the Durban country club, provincial political leader Willies Mchunu (2016) wined and dined 21 European and Asian ambassadors and embassy officials, and leading business representatives. In spite of growing criticism from environmentalists, corruption critics and South Durban residents, Mchunu (2016) spoke glowingly of Durban's port expansion, even while the project was facing a long delay due to the lack of shipping demand:

The development and expansion of the ports are of national importance and a key pillar of the Presidential Infrastructure Coordinating Commission's Strategic Infrastructure Project Two, and also part of the National Planning Commission's National Development Plan (NDP), which looks forward to 2030. Durban's port can accommodate 2.9 million containers, but its expansion and a new excavated port would increase its capacity to more than 20 million. Transnet, the agency responsible for the ports, is predicting that at an 8 percent annual growth rate in containers coming through the port, the existing infrastructure will reach its limit in 2019 and a lack of container capacity will hamper economic growth.

Mchunu's pitch and indeed the 2012 NDP's underlying logic were profoundly flawed. ${ }^{7}$ Not only is there is absolutely no chance to raise annual goods traffic through Durban to 20 million containers by 2040 . On the contrary, the deglobalization process will negate the city's vision for future mercantilist prosperity (Bond 2017). Still, Mchunu's appeal for FDI in a port-petrochemical complex today dominated by Shell, BP and the Malaysian-owned Engen is fanciful, but also dangerous. Indeed, local officials are offering sweetheart deals to transnational corporate players in conjunction with South Africa's ersatz Blue Economy strategy, known as Operation Phakisa: Oceans Economy. Phakisa - meaning 'hurry up' in the local Sesotho language - is the nickname for a new South African narrative: foreign firms will readily invest in the Blue Economy, seeking out sea-side opportunities for capital accumulation (a tiny component is dedicated to marine sustainability).

Ocean-based mega-project development was justified with Blue Economy rhetoric starting in 2014, also in Durban (Masie and Bond 2018). President Jacob Zuma, who led the country through what his successor Cyril Ramaphosa termed "nine lost years" (2009-2018) due to widespread corruption (Bishop 2019), launched the Oceans Phakisa with McKinsey's assistance in Durban. The state's urge to capitalize on emerging Blue Economy rhetoric to attract multinational corporate investment soon became a central feature, one endorsed by Ramaphosa (Zuma was fired by his party 15 months earlier than anticipated, due to his family's own indefensible connections to the Gupta brothers).

The extractivist mind-set was evident at Phakisa's birth in Durban's Riverside Hotel, just across the Umgeni River from the Durban Country Club. There, in an unusual burst of bureaucratic planning over a sixweek period in mid-2014, a 'big fast results' methodology gave birth to Phakisa. Zuma's 2013 visit to Malaysia had introduced the nomenclature, process and strategy to South Africa, and the international consultancy

\footnotetext{
7 The main problem with the NDP - which from 2009-2014 had Ramaphosa as deputy chairperson - was a fetish for corporate-led extractivist growth. The Durban mega-project joins another US\$60 billion NDP plan: to rehabilitate rail lines and expand the coal terminal at the main port north of Durban, Richards Bay, already one of the world's largest. The primary aim of that project - the first priority of the NDP's Presidential Infrastructure Coordinating Commission - is to export 18 billion tons of coal, of which currently nearly three quarters go to India and East Asia, and a quarter to Europe (National Planning Commission 2012).
} 
McKinsey was chosen to manage the process. ${ }^{8}$ Zuma's (2014) stated objectives of 'growing' ocean-related business activities focused primarily on shipping and offshore fossil fuel exploration, as well as seabed mining and factory fishing (Republic of South Africa 2014).

Phakisa strategies are running afoul not only of the extremely volatile global economics discussed above. The conversion of nature into capital and attempts at what Zuma (2014) called 'deriving value' from ecosystem services are also under increasing threat from climate change. Instead of Operation Phakisa, a 'Just Transition' approach to decarbonizing the ocean and coastline is needed, against the mercantilist, climatecatastrophic mode of Blue Economy capital accumulation in South Africa. But to make such an advance, more critical thinking is needed about offshore oil and gas - and a larger coalition than simply climate-focused NGOs will be required to mount an effective offensive.

\section{Phakisa and climate chaos}

The main dilemma for climate-conscious planners is the vast deep-water fossil fuel reserves discovered in the late 2010s. Nearly four decades earlier, in 1982, an ocean-extractive sensibility was fostered in the United Nations Convention on the Law of the Sea, giving priority to capital's geopolitical and property-right imperatives. Dating to the 17th century's 'freedom of the seas', interstate agreements on the extension of sovereign territorial coastline rose from three nautical miles ( $4.8 \mathrm{~km}$, a cannon shot's distance) to today's twelve nautical miles $(22.2 \mathrm{~km})$. Nearly all national states with coastlines made attempts to colonize ocean areas in order to exploit fish stocks and minerals, reaching out from the shoreline a full 200 nautical miles (370 km), where countries claim control over all marine resources, including oil and gas.

South Africa's reach extends beyond immediate mainland borders into an area 1.5 million square kilometres large (including loosely-affiliated distant islands), a major challenge to security and legal order (van Wyk 2015). The very depths of the terrain include trenches four kilometers deep, some within the Outeniqua Basin and some below the treacherous Agulhas Current offshore from Durban, both considered sites likely to contain massive oil and gas deposits (SA Info 2006). Like much of the rest of the nearly 3,000-kilometer-long South African coastline, these new opportunities are being assessed by the world's largest oil companies, with great hype about the resulting benefits to society.

In early 2019, in Outeniqua's Brulpadda block, the French firm Total discovered a billion oil barrelequivalents of oil and gas, valued at US\$80 billion, which meant, on the one hand, "With this discovery, Total has opened a new world-class gas and oil play and is well positioned to test several follow-on prospects on the same block" (Total 2019). On the other hand, the Brulpadda discovery represents a major threat to South Africa's already half-hearted commitment to emissions cuts, in the Paris Climate Agreement (Bloom 2019). Offshore Durban, ExxonMobil and Norway's Statoil are exploring in one block, accompanied next door by Italy's ENI and the formerly South African (now New York-financed) oil-from-gas producer Sasol. ${ }^{9}$

\footnotetext{
${ }^{8}$ Within three years that firm came under attack because of its links to the Gupta brothers. The opposition centre-right Democratic Alliance filed a lawsuit against McKinsey for fraud, racketeering and collusion. Kickback allegations were drawn from leaks within a damning Gupta-related email cache (AmaBhungane and Scorpio 2017), which soon destroyed the financial empire of the three brothers, who took refuge in Dubai. By early 2018, as Zuma was relieved of the presidency by Ramaphosa, prosecutions of the network began, but fitfully. McKinsey offered to repay Eskom. But by 2019 there were so many other 'state capture' critiques underway that the consultancy managed to avoid the kind of opprobrium that led to the 2017 bankruptcy of a British public relations firm linked to the Guptas, Bell Pottinger (see footnote 10).

${ }^{9}$ Sasol has the notoriety of emitting more CO2 in any point source on earth, in the coal-to-oil operation it runs in Secunda, South Africa.
} 
According to Phakisa planners (a group that includes the oil majors), "South Africa has possible resources of 9 billion barrels oil and 11 billion barrels of oil equivalent of gas" amounting to 40 and 375 years, respectively, of local consumption (Republic of South Africa, 2014: 1, 11) (Figures 3 and 4). Depths and distance from shore are extreme in South Africa. But across the world, more than a third of oil and gas resources are offshore, and a quarter of that is in deep water, according to the United Nations (2012: 11): "market pressures are making the exploration for and tapping of evermore remote reserves cost effective, bringing the most isolated areas under consideration. Methane hydrates, a potentially enormous source of hydrocarbons, are now also being explored and tapped from the seabed." But there are also profound contradictions to explore, including the degree to which climate change makes the oil rigs extremely dangerous in an era of extreme ocean storms, such as hit Durban so hard in October 2017 and April 2019, as discussed below.

\section{Multiple organisations spanning the public and the private sector as well as academia have participated in the oil and gas lab}

(ivi) public enterprises
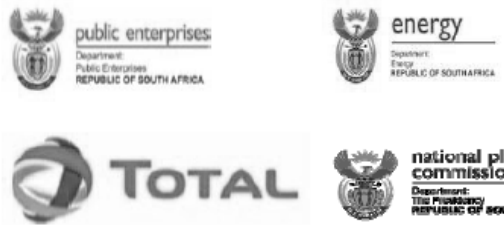

(S) Eskom
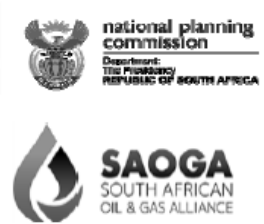
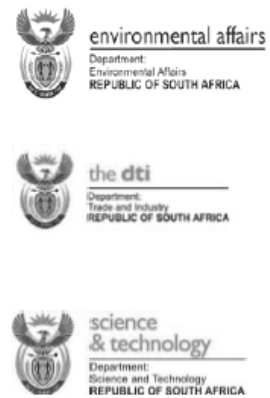

science \& technology

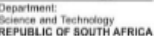
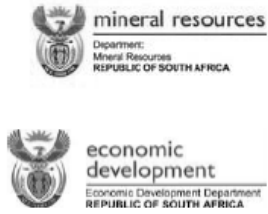

(1) performance monitoring and evaluation

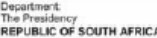

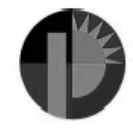

Petrosa
OPASA
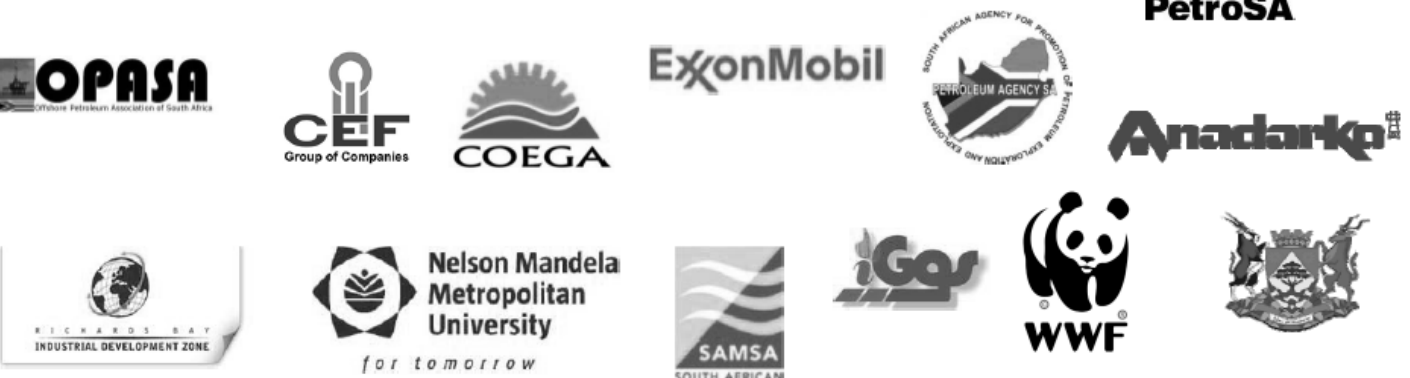

Nelson Mandela

Metropolitan

University

for tomotrow

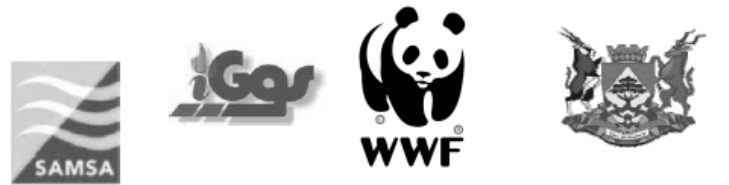

Figure 3: Participants in Operation Phakisa: Oceans, July 2018 Source: Operation Phakisa: Oceans (in mid-2014 the exchange rate was R11/\$)

In addition to oil and gas interests, the main driver of Phakisa is Transnet. Not only is the firm notoriously corrupt, but Durban and the three other main container ports in South Africa are also increasingly uncompetitive as the platforms for 'gateway to Africa' trade, because they charge nearly twice as much per unit for handling containers as do average ports in the rich countries (Pieterse et al. 2016). Durban's recent annual levels of 2.5-2.7 million containers a year represent the largest such facility in Africa. However, Transnet's 
borrowing and locomotive acquisition (both from China) during the 2010s implicated the firm's leaders in mark-ups that benefited cronies of Zuma. Executive firings followed in 2018-2019. ${ }^{10}$

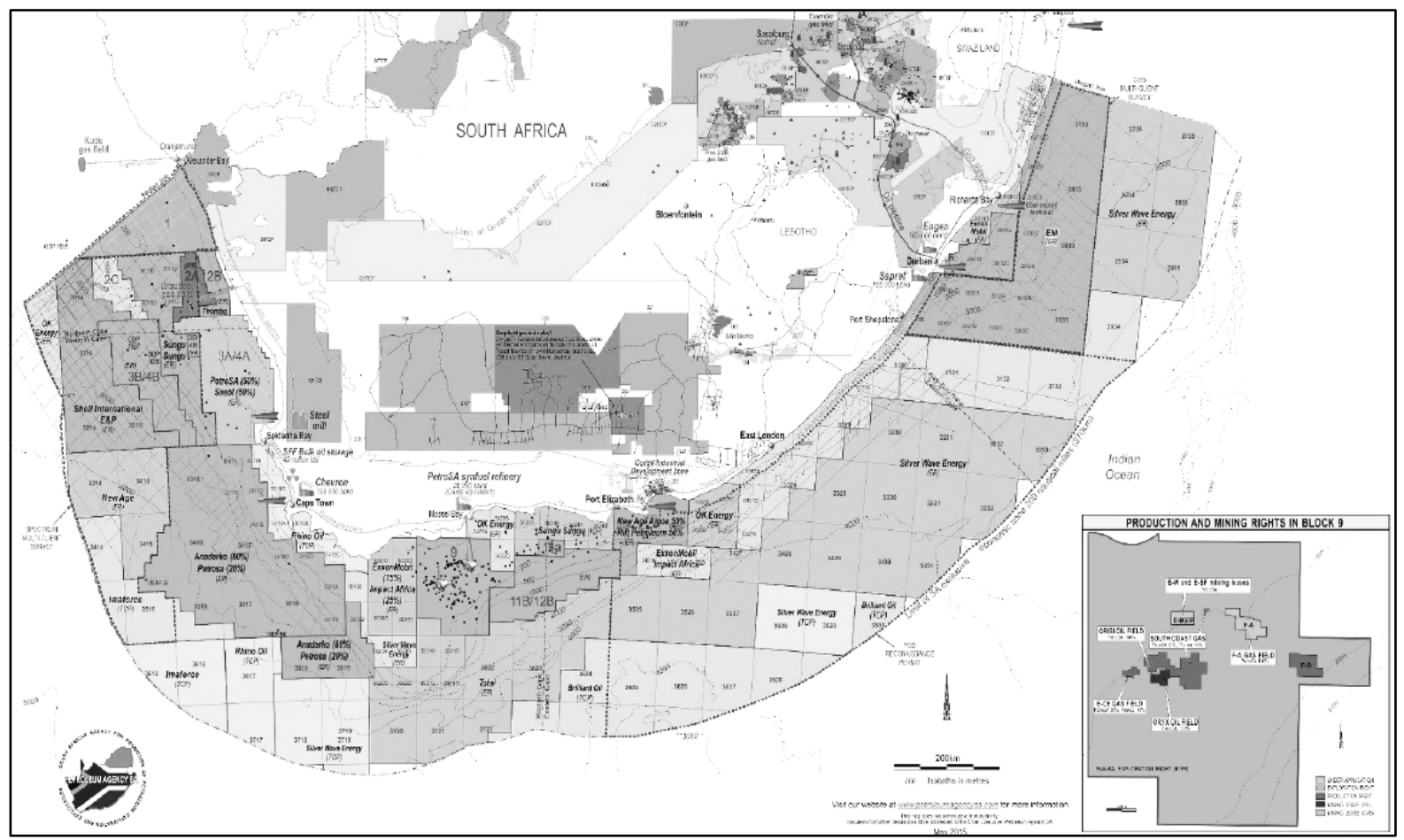

Figure 4: South Africa's fossil fuel reserves including offshore exploration blocks, 2018. Source: PetroSA.

It appears that internecine competition between ports is now a major factor in new investment planning. Durban remains a high priority not only for a regional politician like Mchunu (2016) trying to impress European diplomats and investors. In addition, Toyota South Africa CEO Johan van Zyl insisted in 2012,

Durban as a brand is not strong enough to simply say 'come and invest in Durban'. What it needs to attract investors are big projects. Durban needs to keep ahead of the competition. China is building ports they don't even know when they will use. If return on investment is the line of thinking we may never see the infrastructure. (Naidoo 2012)

In the same spirit three years later, Transnet official Zeph Ndlovu (also head of the Durban Chamber of Commerce and Industry) announced:

\footnotetext{
10 The same corrupt nexus at Transnet that emerged around the Gupta brothers (three Indian immigrants) was responsible for the mid-2017 collapse of London public relations firm Bell Pottinger due to its unethical practices in South Africa. This was followed by unprecedented pressure on local offices of McKinsey and KPMG once their Gupta-related corruption was uncovered in a leaked email cache. The revelations included information about a US\$5 billion loan granted to Transnet by the China Development Bank at the 2013 Durban BRICS summit, which allowed the parastatal to systematically overpay (by US\$1.3 billion) for several hundred locomotives (from China South Rail) for both coal and general freight use, thanks to an apparently brazen backhander (of US\$400 million) to the Gupta network. Many of the locomotives did not comply with Transnet's localization requirements. Likewise, the Chinese sale of seven container cranes for the Durban port cost Transnet US\$92 million, of which US\$12 million was a kickback (amaBhungane and Scorpio 2017).
} 
We have to press ahead, and if we are to unseat our competitors up north, we can't win this battle if we pull back every now and then and look at accounting principles... Nigeria has five active ports and they have two other ports under construction, likely to increase their capacity from one million Twenty-foot Equivalent Units to 3.5 million TEUs. Namibia is also expanding, and in all these examples, China is actively funding and building infrastructure... We postpone the plans at our peril. (Comins 2015)

In his 2016 budget speech, then Finance Minister Pravin Gordhan (2016) was supportive of Transnet's expansion: Building on the Phakisa oceans economy initiative, a US\$700 million investment in rig repair and maintenance facilities at Saldanha Bay is planned, and work has begun on a new gas terminal and oil and ship repair facilities at Durban. Transport and logistics infrastructure accounts for nearly US\$22 billion over the next three years." Gordhan continued, "Transnet is acquiring 232 diesel locomotives for its general freight business and 100 locomotives for its coal lines."

Aside from the notorious locomotive procurement fraud, the central question that Gordhan begged was the extent of economic demand for either container traffic moving from road to rail, or coal exports. During the early 1990s, transport deregulation allowed wholesaling firms to shift containers from rail to road (hence adding flexibility in destinations). One result was the construction of massive new warehousing and logistics facilities along the main Durban highways, where imported containers are unpacked and repacked in the wholesale trade. This happens far from the rail lines and there is not much prospect of a return to past container transport geographies, no matter how desirable a road-to-rail strategy is for many reasons (especially safety, since thousands of truck accidents occur in Durban each year) (Bond 2017).

The second concern, demand fluctuation, is worth considering in more detail because so much of the anticipated Blue Economy port investment relies upon high prices for commodity exports. Moreover, not only are many of South Africa's commodity prices dropping dramatically from their 2008-2015 highs, the main bulk export on the Indian Ocean is coal. A full cost-accounting of the damage done by coal at local and global scales would negate its merits as a contributor to the Blue Economy GDP derived from bulk shipping.

Moreover, an additional factor would make full-cost accounting of commodity exports highly undesirable to advocates of commodity exports: the non-renewable resource depletion that occurs without compensating reinvestment. This process has caused the continent's wealth - measured to include resources termed (by ecological modernizers) 'natural capital' - to fall rapidly since 2001. ${ }^{11}$ The application of natural capital accounting was promised by South African environment minister Edna Molewa in 2012 when signing the Gaborone Declaration for Sustainability in Africa (2012: 1), i.e, "to integrate the value of natural capital into national accounting and corporate planning and reporting processes, policies, and programmes." Since 2012, no efforts have been taken to adjust the NDP or enforce the counting of resource depletion - perhaps because, as argued below, the results would militate against most South African and African extractive systems on economic grounds.

Estimates of how rapidly natural wealth is depleting should be central to assessing the extractive industries whether onshore or offshore, and in many cases such a calculation would make the case that until countries achieve local control of their own resources, minerals and oil should be left in the soil, or under the ocean bed (Bond 2018). ${ }^{12}$ For oil, the compensation due from the North - as a down-payment on "climate debt"

\footnotetext{
${ }^{11}$ Even the World Bank (2014: vii) admits that 88 percent of Sub-Saharan African countries suffered net negative wealth accumulation in 2010. In absolute terms, the Bank also acknowledges that this depletion of wealth amounted to 12 percent of the sub-continent's US\$1.36 trillion GDP in 2010 alone, i.e. US\$163 billion (and far more if the major North African oil-rich countries are included). The Bank's most recent, rigorous accounting exercise, The Changing Wealth of Nations 2018 (Lange et al. 2018) revealed similar declines. Even without incorporating platinum and diamond markets or North African petroleum depletion, Lange et al. (2018: 63) applied the measure 'Adjusted Net Savings' so as to correct for natural capital depletion, and found that Sub-Saharan Africa was the only region with net losses, "averaging negative 3 percent of GNI over the past decade, suggesting that its development policies are not yet sufficiently promoting sustainable economic growth."

${ }^{12}$ For example, grassroots activists critical of diamond extraction in eastern Zimbabwe, oil in Nigeria, and coal, platinum, and titanium in South Africa regularly insist on leaving resources in the ground. A similar argument is applied to the South
} 
owed Africa - simply on grounds of climate change mitigation would be substantial. ${ }^{13}$ As argued in detail by Masie and Bond (2018), these aspects of ecological modernization should in theory cancel out the advantages to a national economy, from ocean extractivism, whether fossil fuels or undersea minerals. There is, in South Africa, thus a distinct lack of interest in pursuing these kinds of accounting exercises.

Phakisa is, in sum, not worth the hype invested in either its modest ocean sustainability components or its more ambitious job creation and investment potential, for reasons largely associated with global capitalist contradictions of the sort discussed above. Still, although FDI and trade-related capital might be scarce, thus making it harder for investors to justify the Blue Economy ocean-grab, there is nevertheless a countervailing force: increasing desperation associated with what might be considered the quickening extractivist 'metabolism', as Joan Martinez-Alier (2002) describes the neoliberal era's relations between global capital and local ruling classes on the one hand, and society and nature on the other.

\section{From Blue Economy to Just Transition: early resistance and transformation narratives}

Clapp et al. (2018: 81) are concerned that "deep-sea mining interests as well as large environmental NGOs have successfully leveraged the Blue Economy framework as a new vehicle for enabling finance capital to penetrate marine areas." But capital's rhetorical success may not translate into sustainable profitability. The contextual analyses above - especially regarding the limits of capitalist expansion (over accumulation), the limits of the spatial fix (deglobalization) and the limits of the temporal fix (excessive financialization and then debt crisis) - help us better understand why we can look offshore to identify new frontiers of accumulation by dispossession. ${ }^{14}$ As argued above, capitalism's shifting, stalling and stealing may not only run into internal contradictions so evident across the Blue Economy, and specifically in the Oceans Phakisa project. In addition, there are early signs of resistance which could take a more expansive form than has so far been the case, in which the first lines of contestation against ocean-based accumulation were standard marine conservation, small-scale fishing and eco-tourism - some of which were readily coopted into Blue-Economy sustainability framing.

Writing initially about Phakisa as it first gained momentum, Masie and Bond (2018: 330) argued that such "mega-project strategies must have their technological and rhetorical assumptions disrupted, underlying economic assumptions questioned, environmental risks recalibrated, and leadership displaced by progressive, democratic forces." That remains true, but was far too self-referential an approach, as if the power of ideas would be persuasive, in a context of economic desperation, ecological irresponsibility and rampant crony capitalism.

After all, the President who replaced Zuma in 2017, Ramaphosa, had returned to politics immediately from his privately-owned Shanduka mining empire (centered on coal). His closest business partner, the billionaire Puthuma Nhleko who took over Shanduka in 2014, had a 10 percent share (along with Qatar Petroleum and Canadian Natural Resources Limited) in the Total Brulpadda oil find (Wasserman 2019). Ramaphosa's closest family relatives - sister-in-law Bridgette Radebe and brother-in-law Patrice Motsepe, all three of whom ranked amongst the dozen richest South Africans, and who were joined by another brother-inlaw, Energy Minister Jeff Radebe - were already benefiting enormously from coal extraction and export. We

Asia Seas by Maria Corazon Ebarvia (2016, 26): "It is essential to recognize natural capital as a critical economic asset and as a source of public benefits." She continues, in a powerful appeal to consider renewable maritime natural capital: "The impact on climate change from the fossil fuel energy sector will put increasing pressure on the energy sector to invest in alternative renewable technologies in the future. Ocean energy offers the potential to be a large source of energy." In South Africa, Masie and Bond (2018: 326) argue against local researchers who attempt to make positive net present value calculations of offshore ocean oil and gas as ecosystem services, without even attempting to assess the negative impact of natural capital depletion when they are extracted.

${ }^{13}$ Such a strategy was attempted in Ecuador's Yasuni National Park, and while it failed in the short run (2007-2013), it is in the process of being revitalized, so as to compensate historically-exploited fossil fuel-rich areas.

${ }^{14}$ Of course, Big Data's new human surveillance and marketing abilities, Artificial Intelligence and outer space - whether Donald Trump's militarization or Elon Musk's commercialization of inter-terrestrial travel - will open up new frontiers at the most micro biopolitical and most macro geopolitical scales. 
warned, "the task of facilitating a Just Transition quickly runs up against an even more powerful logic: clientelist politics in the African National Congress's factional patronage networks" (Masie and Bond 2018: 330). This was actually a Zuma-era underestimation of the adverse power relations that would be amplified after 2018.

All of this sets up the kinds of conflict South Africans know so well: between new rhetorics of 'sustainable development' that disguise old systems of profit on the one hand, and resistance directed towards more transformative visions on the other. The country's progressives have encountered this dichotomy repeatedly, and on five occasions have fought successfully against power and profit: ending apartheid (1970s1990s); winning free household supplies of water and electricity (1998-2001); getting AIDS medicines price reductions from \$10,000/year to free and thus raising life expectancy from a low of 52 to 64 years (2000-2005); fighting off corruption within the state and allied multinational corporations (2013-2017); and demanding free tertiary education for nearly all students who qualified (2015-2017). In this context, debates over how to manage ocean resources offer another glimpse of this potential Polanyian double movement, in which extreme commodification meets not only resistance but in some cases, impressive new gains for oppressed people.

But political clarity is vital, and it is worth recognizing the potential for confusion as a result of semantics. Before 2009, two terms that later became common within sustainability narratives were rarely if ever uttered: 'Blue Economy' and 'Just Transition' (Figure 5). Their use has subsequently exploded, but exactly what kind of Just Transition is being conceptualized in South Africa? The term is thrown around in official circles in frivolous ways, e.g. by Radebe (2018) and Ramaphosa (2019), at the same time that the state projects an increase in fossil fuel-supplied energy capacity from 2018 levels of 30,000MW, to 46,000MW by 2030 (Radebe 2018). The 2017 National Climate Change Adaptation Strategy mentions Phakisa aquaculture strategies twice in passing, and Just Transition only once, but doesn't otherwise grapple with climate change, oceans and the Blue Economy (Republic of South Africa 2017).

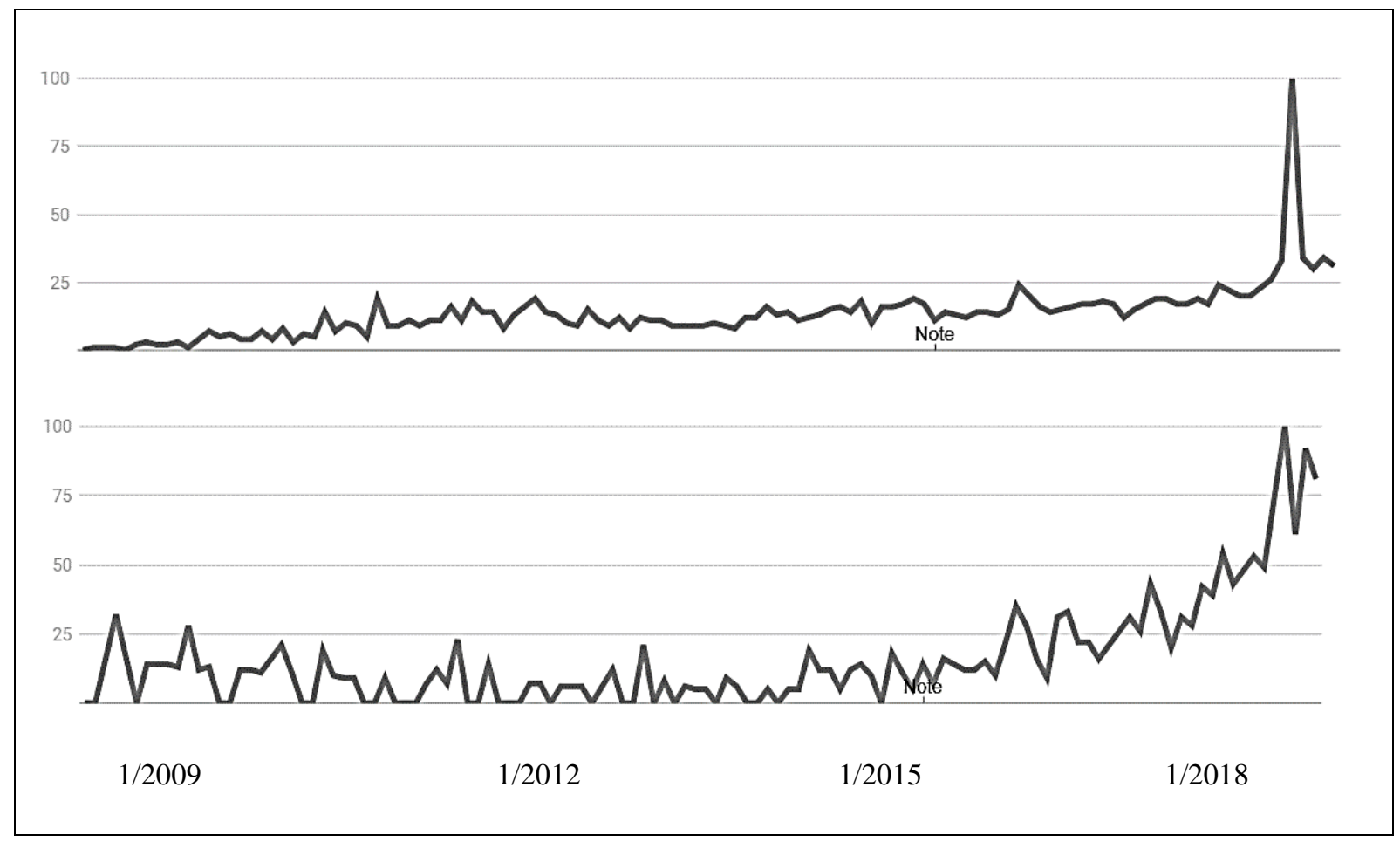

Figure 5: Google-trends mentions of 'Blue Economy' (top) and 'Just Transition' (bottom), 20092019. Source: https://trends.google.com/trends/ 
In contrast, there are more rigorous formulations of the Just Transition associated with South Africa's eco-social justice groups, such as the Alternative Information and Development Centre's (2017) Million Climate Jobs campaign and Vishwas Satgar's book on The Climate Crisis (2018). Given the highly adverse power relations, however, local activist groups eschewed the temptation to blueprint a Just Transition, although in April 2019 Greenpeace Germany (2019) released a major study on how to transfer South African workers from coal mines to renewable energy jobs (which in turn would have major implications for anticipated coal exports from Richards Bay), also acknowledging that the very few employment opportunities in global-scale ocean-related renewable energy (just 2,500 in 2015) could be raised to more than 620,000 by 2050 .

Such visioning aside, the primary objective would be to reassert a green-left politics sufficiently strong as to dislodge the ruling party from power, perhaps as early as the 2024 elections given the organization's durable split into the pro-Ramaphosa neoliberal and pro-Zuma populist-patrimonial factions. In the future, new politics will begin to reflect climate consciousness, as extreme-weather incidents - such as Cyclones Idai and Kenneth (devastating neighboring Mozambique) and Durban's so-called rain bomb, both in 2019, or Cape Town's 2017-2018 drought and water crisis - become more common, and as a youth consciousness builds up with long-overdue generational rage (witnessed in global 'Climate Strike' activism). A political party with more explicit Just Transition policies may mature in the 2020s to build a winning national coalition (similar coalitions proved feasible in 2016 municipal elections that unseated the ruling party from its post-1994 rule of Johannesburg and Pretoria).

By way of comparison, in a context of equally difficult power relations, the United States 'Green New Deal' - catalyzed in late 2018 by Sunrise Movement youth who occupied House Speaker Nancy Pelosi's office - has generated enormous interest and even some specific ocean-related strategies. David Helvarg and Jason Scorse (2019) argue the case for new flood insurance, coastal infrastructure focusing on strengthened natural barriers and coastal habitats, expansion of offshore renewable energy production, adaptation support for ports and fishing communities, more marine protected areas, a renewed commitment to aquaculture investment, and a better National Disaster Recovery Framework drawing in part on the military. All of these make sense as adaptation reforms for application in South Africa, though they are grounded more within ecological modernization than Just Transition values.

In search of the latter, it is more appropriate to initially consider bottom-up formulations, such as reconstruction of more architecturally-sound structures and greater storm-water drainage capacities, sufficient to prevent the loss of life and housing that devastated Durban in 2019. In South Africa, at least two ideal-type kinds of micro-geographic resistances making Just Transition demands are located on the Indian Ocean: a rural coastal community threatened by titanium mining on the 'Wild Coast' sands of Xolobeni, defended by the visionary, militant Amadiba Crisis Committee (2016); ${ }^{15}$ and the South Durban Community Environmental Alliance (SDCEA) which likewise has articulated an alternative post-fossil philosophy, based at the site of Africa's largest refinery, and one also closely related to shore-based fisherfolk rights (since in this respect, SDCEA has been the single most important network in Durban) (SDCEA 2008; Bond 2017). ${ }^{16}$ Both groups

\footnotetext{
${ }^{15}$ In Xolobeni, the Australian mining firm Mineral Commodities Ltd, seeks to displace 500-1,000 residents from 2,900 hectares of beachfront land containing 9.3 million tonnes of titanium at the world's tenth largest deposit. The ACC is, in contrast, promoting Wild Coast eco-tourism and traditional farming (ACC 2016; Masie and Bond 2018; Washinyira 2016). While grassroots battles against the national mining Minister, the Australian firm and its local proxies continued as this article went to press, the main judicial battleground in 2018 was over whether a community with collective land tenure rights, as represented by the ACC, had the legal power to turn down mining licence applications. Victory there in the first round, the High Court, was won in September 2018, but the state vowed to appeal. A final court win would confirm sufficient security to expand alternative strategies consistent with a Just Transition that values local autonomy, preservation of indigenous values, and expansion of harmonious society-nature relations.

${ }^{16}$ SDCEA has made various post-carbon development demands for the South Durban Basin (SDCEA 2008, SDCEA 2011, Bond 2016). These include reversing the liberalized zoning that has allowed freight transport to creep into historic Clairwood, displacing thousands of black households. SDCEA also demands more green space in the toxic-saturated industrial and petrochemical areas. As an antidote to Operation Phakisa, SDCEA's 30-page Spatial and Development Vision includes demands such as "a halt to the privatization of ocean, Bay and shore resources that belong to all the people of this country" (2008).
} 
have had some remarkable successes on defensive terrains (Masie and Bond 2018). However, what is now needed is a much more profound and geographically-scalable resistance narrative and practice, one drawing more from concern about climate change, with anti-corporate strategies and tactics that will challenge not just regulators but also legislators and the judicial system.

Climate argumentation is increasingly common when environmental justice groups and their lawyers engage the state, challenging what tend to be rubber-stamped Environmental Impact Assessment (EIA) processes. One battle was waged against the main Oceans Phakisa investor, Transnet, in late 2013. In an unusual turn of events, its Durban port-deepening EIA was rejected by national government's environment staff because the parastatal had neither properly assessed the damage to the harbor's famous sandbank - with its vital role in ecosystem maintenance (including bird and sealife spawning grounds, as pointed out by an NGO, Birdlife South Africa) - nor accurately gauged the impact of sea-level rise and severe storms (Paton 2014). Extreme weather events caused by climate change could swamp and maybe destroy the US\$480 million investment in the first stage of the Durban port's expansion, according to Transnet critics. In mid-2014, SDCEA researchers used another EIA challenge to flesh out the sea level rise threat. Transnet's previous filings downplayed rising waters and extreme storm damage, even though the firm's own Durban infrastructure was badly damaged in 2012 when big waves - caused in part by the harbor entrance's deepening and widening pushed a ship into container cranes. Amid suggestions that Transnet was 'climate denialist' about the port expansion (Paton 2014), the parastatal continued to file EIAs with 2060 estimates of only 0.58 meters sea level rise. Rising evidence of potential runaway ice melting in the Antarctica, Arctic and Greenland was ignored.

To illustrate the danger of storms in the large Durban harbor area, in October 2017, one was sufficiently strong to break a large cargo vessel free of its port moorings, and it floated into the mouth of the harbor. After a collision with another vessel, two containers fell off the boat. They were packed with 2.5 billion nurdles: plastic resin pellets with the shape and size of a lentil, in this case stored in 2,000 bags, weighing 50 tons. The nurdles rapidly migrated from the harbor into ocean currents. Only an estimated billion were recovered by Durban authorities and citizens, and so within a year, nurdles from the Durban spill were found on Australian beaches (Gubana 2018). Meanwhile, the impact of their toxicity expanded as they broke into ever-smaller micro-plastics and were consumed by fish. And in April 2019, another storm dropped 165 milimeters of rain within 24 hours just south of the harbor, killing 65 Durban residents mainly as a result of collapsed residential structures (this was a record downpour, more than 50 percent worse than the October 2017 storm). Even Ramaphosa was compelled to admit, "This is partly what climate change is about, that it just hits when we least expect it" (Reuters 2019).

This stage of port expansion was not the first time Transnet had been challenged on climate change grounds. In a 2008 EIA for Transnet's doubling of pumping capacity through the Durban-Johannesburg oil pipeline, SDCEA accused the firm of ignoring the implications for climate change, as well as siting the line in an environmentally-racist manner insensitive to the damage the South Durban refineries were doing to society and local ecology (Bond 2017). Transnet had detoured the new pipeline hundreds of kilometers through South Durban and Umbumbulu instead of the traditional direct route to Johannesburg that passes through wealthy white-dominated residential, equestrian and farming areas. Speaking frankly when describing that project, former public enterprises minister Malusi Gigaba (2012) conceded "systemic failings... Transnet Capital Projects lacked sufficient capacity and depth of experience for the client overview of a megaproject of this complexity. There was an inadequate analysis of risks." As Gigaba admitted, "Transnet's obligations on the project such as securing authorizations - EIAs, land acquisition for right of way, water and wetland permits were not pursued with sufficient foresight and vigour."

Further EIA filings by SDCEA and other enviromental groups and lawyers increasingly stressed climate change damage, especially against Transnet and the national electricity supplier Eskom's coal-fired power plants. With resistance rising, in 2014, the original Phakisa planners admitted the obvious contradictions associated with "potential real and perceived environmental risks." ${ }^{17}$ By late 2018, SDCEA's leader Desmond

\footnotetext{
${ }^{17}$ Specifically they listed "concerns about the negative impact of offshore oil and gas exploration and exploitation of the environment; ... concerns about our capacity and will to implement an effective oil and gas environmental governance regime; and lack of understanding and/or suspicion of governance systems" (Republic of South Africa 2014: 275).
} 
D'Sa (2018) committed to forcefully contesting all these firms' EIA statements. When initiated by fossil fuel corporations, they typically lack integrity due to the firms' enormous power and endless dishonesty. Even New York's state attorney general sued ExxonMobil last month because of its "longstanding fraudulent scheme... concerning the company's management of the risks posed to its business by climate change regulation."

Meanwhile, in 2018, mainstream conservationists as well as progressive environmentalists - e.g. a new 'Oceans not Oil' (2018) campaign allied to SDCEA - hoped that the state's declaration of at least 5 percent of the coastal waters as Marine Protected Areas that year would begin an organic resistance process. Parts of the shoreline could finally heal, especially after the campaign identified an unusually high number of beached whale carcasses, not long after the oil companies' seismic testing began.

At the global scale, fusions between conservationists and fisherfolk were sought by networks including La Vía Campesina affiliates, the World Forum of Fisher Peoples and the World Forum of Fish Harvesters and Fish Workers (2017) during recent United Nations debates on marine sustainability. The latter, however, declared that such meetings did not stress human rights, and thus left fisherfolk "at the fringe of participation, while providing influential space for the corporate sector and large NGOs."

Similarly, at a higher scale, in spite of extensive (but unsatisfactory) civil society participation (Bond 2016), the 2015 Paris Climate Agreement had confirmed Africa's victimization, just as surely as did Cyclone Idai's 1,000+ deaths and mass socio-ecological-economic destruction just over three years later. Often led by Pretoria, BRICS government delegates had worked inside the UN climate summits - most explicitly in the 2009 Copenhagen Accord and 2011 Durban Platform - in close alliance with the two main historically dominant greenhouse gas emitters, the United States and European Union (Bond 2012). The Paris deal was celebrated by polluters, given that the (weak) emission-cut commitments are non-binding (with no legal accountability for violations or for default, in the case of Trump), and also that there is no longer a prospect of legal liability (the "climate debt") against the wealthy countries for their role in what are likely to be 200 million additional African deaths this century due to extreme weather, droughts, and increased temperatures (Borràs 2019). Nor are military, air travel or shipping emissions included (Bond 2016).

The dilemma is that in all these areas, the most substantial force in South African left politics - the trade union movement - was uninvolved, or even actively hostile. There are enormous potentials for post-carbon perspectives from labor, for example, as articulated by the National Union of Metalworkers of South Africa (Numsa). The 2010-2015 Numsa strategy was as visionary as that of any labor movement ${ }^{18}$, yet its most important advocacy experts and campaigners are no longer with the organization. Hence in 2018 Numsa battled both the state and Greenpeace which (mistakenly) supported a dramatic increase in privatized solar power plants. But Numsa was (mistakenly) intent on saving jobs at the coal-fired powerplants due to be shuttered as a result of their old age. The necessary red and green fusion was, in this instance, elusive, in spite of Numsa's declaration of support for socially-owned renewable energy.

These kinds of decommodification demands - ranging from valorizing peasant social relations (Xolobeni) to post-pollution urbanism and fisherfolk rights (South Durban) to radical red-green visions of renewable energy production and consumption (Numsa et al.) - are the basis for a politics that replaces Oceans Phakisa with an ever more urgent democratic eco-socialist agenda. The coalitions and alliances required to achieve this are not simply on the horizon; they must be carefully constructed, especially if climate change is an all-encompassing link issue (Bond 2012; Klein 2014). The struggle against projects such as Oceans Phakisa will be won not by default thanks to conditions of worsening capitalist crisis, nor in dazzling technicist argumentation, and nor because of activists' defensive critiques alone.

However, the Phakisa team left these without sufficient resolution, pledging only weak post-pollution initiatives: "Conduct emergency response drills also as industry to initiate the creation of a world-class oil spill response capacity in South Africa; make the International Oil Pollution and Compensation Fund operational" (Republic of South Africa 2014: 31).

18 To illustrate, at a 2015 Electricity Crisis Conference, Numsa and its allies (2015) declared, "The electricity crisis poses the opportunity to mitigate against global warming and move away from fossil fuel to renewable energy." Numsa et al.'s arguments (2015) allow scoping of renewable ocean and coastline energy with these features: "The renewable energy sector that we are demanding must be socially-owned; meaning a mix of publicly-owned energy entities, energy co-operatives, community-owned enterprises and municipal-owned energy entities." 
Replacing the Blue Economy's accumulation logic with a much greener and redder Just Transition will occur only with visionary ambition and ideological clarity about what is at stake. And that, in turn, can only be forged in ever more intense eco-social struggle, as tinkering-type reforms fall flat and radical openings necessarily emerge. These are the counter-threats to Operation Phakisa and the Blue Economy: not only the self-inflicted damage of capitalist economics and the worsening impacts of climate change on the vulnerable coastlines, but also the social and environmental defenders of ocean life.

\section{References}

Alternative Information and Development Centre. 2017. Million climate jobs. Cape Town. http://aidc.org.za/programmes/million-climate-jobs-campaign/about

AmaBhungane and Scorpio. 2017. Guptaleaks. Johannesburg. 18 September, http://amabhungane.co.za/article/2017-09-18-guptaleaks-a-third-gupta-transnet-kickback-contractunearthed

Amadiba Crisis Committee. 2016. About the Amadiba crisis community and the region. Unpublished report. Xolobeni, South Africa. http://www.benchmarks.org.za/press/amendments_accepted_in_annexure_a.doc

Bavincka, M., S. Jentoft, and J. Scholtensa 2018. Fisheries as social struggle. Marine Policy 94 (2018) 46-52.

Bennett, N.J .2018. Navigating a just and inclusive path towards sustainable oceans. Marine Policy 97: 139146.

Bishop, C. 2019. \#WEF19: "We have the loss of nine years to make up", CNBC Africa, 24 January. https://www.cnbcafrica.com/insights/world-economic-forum/wef-davos-2018/2019/01/24/wef19-wehave-the-loss-of-nine-years-to-make-up-sas-president-ramaphosa/

Bloom, K. 2019. South Africa's offshore gas strike. Daily Maverick, 2 February. https://www.dailymaverick.co.za/article/2019-02-12-south-africas-offshore-gas-strike-its-all-goodright

Bond, P. 2012. Politics of climate justice. Pietermaritzburg: University of KwaZulu-Natal Press.

Bond, P. 2016. Who wins from "Climate Apartheid"? New Politics Winter: 122-129.

Bond, P. 2017. Red-Green alliance-building against Durban's port-petrochemical complex expansion. In L. Horowitz and M.J. Watts (eds.). Grassroots environmental governance: community engagements with industrial development. London: Routledge.

Bond, P. 2018. Economic-ecological narratives for resisting extractive industries in Africa. In P. Cooney and W.S. Freslon (eds.). Environmental impacts of transnational corporations in the Global South. Emerald Publishing. Pp. 73-110.

Borràs, S. 2019. Colonizing the atmosphere: a common concern without climate justice law? Journal of Political Ecology 26: 105-127.

Bracking, S. 2015. The financialization of power. London: Routledge.

Burgess, M., M. Clemencea, R. Grant, R. McDermott, C. Costelloa and S. Gaines. 2018. Five rules for pragmatic blue growth. Marine Policy 87: 331-339.

Business Daily Africa 2017. Activists demonstrate against Centum's coal project. 12 May, http://www.businessdailyafrica.com/news/Lamu-activists-demonstrations-coal-plant-/5395463924620-wo62uw/index.html

Clapp, J., P. Newell and Z. Brent 2018. The global political economy of climate change, agriculture and food systems. The Journal of Peasant Studies 45(1): 80-88.

Comins, L. 2015. Durban dig-out port plan on hold. Daily News, 1 December, https://www.iol.co.za/dailynews/news/durban-dig-out-port-plan-on-hold-1953183 
D'Sa, D. 2018. Why we should stop oil and gas drilling offshore KZN. Daily News, 7 November. https://www.iol.co.za/dailynews/opinion/why-we-should-stop-oil-and-gas-drilling-offshore-kzn$\underline{17804012}$

Ebarvia, M. 2016. Economic assessment of oceans for sustainable blue economy development. Journal of Ocean and Coastal Economics 2(2): Article 7.

Eikeseta, A., A. Mazzarella, D. Brynyildur, D. Klinger, S. Levin, E. Rovenskaya and N. Stensetha 2018. What is Blue Growth? Marine Policy 87: 177-179.

European Commission 2014. Blue growth. Brussels: European Commission. https://ec.europa.eu/maritimeaffairs/policy/blue_growth_en and https://eur-lex.europa.eu/legalcontent/EN/TXT/PDF/?uri=COM:2014:254:REV1\&from=EN

Gaborone Declaration for Sustainability in Africa 2012. Declaration. Gaborone, Botswana, May 12. http://www.gaboronedeclaration.com/

Garcia, A. and P. Bond 2018. Amplifying the contradictions. In L. Panitch and G. Albo (eds). The world turned upside down. London: Merlin Press. Pp. 223-246.

Gigaba, M. 2012. Where the Transnet Pipeline Project went wrong. Statement by the Public Enterprises Minister, Pretoria. https://www.politicsweb.co.za/news-and-analysis/where-the-transnet-pipelineproject-went-wrong--ma

Gubana, B. 2018. Prepare for the great nurdle invasion, as a wave of 1 billion plastic pellets bears down on WA. ABC News, 26 October. https://www.abc.net.au/news/2018-10-26/nurdles-wash-up-near-albanyon-wa-south-coast $/ 10433348$

Gordhan, P. 2016. 2016 Budget speech. Pretoria: National Treasury. http://www.treasury.gov.za/documents/national\%20budget/2016/speech/speech.pdf

Greenpeace Germany. 2019. Case studies from transition processes in coal dependent communities. Hamburg, 10 April. https://storage.googleapis.com/planet4-africa-stateless/2019/04/52eea778-jt-case-studiesreport.pdf

Hadjimichael, M. 2018. A call for a blue degrowth. Marine Policy 94: 158-164.

Hao Qi 2017. Dynamics of the rate of surplus value and the "new normal" of the Chinese economy. University of Massachusetts-Amherst Political Economy Research Institute Working Paper. https://www.peri.umass.edu/publication/item/1003-dynamics-of-the-rate-of-surplus-value-and-thenew-normal-of-the-chinese-economy

Harvey, D. 1982. Limits to capital. Chicago: University of Chicago Press.

Harvey, D. 1989. From managerialism to entrepreneurialism: the transformation in urban governance in late capitalism. Geografiska Annaler. Series B, Human Geography 71 B(1): 3-17.

Harvey, D. 2003. The new imperialism. Oxford: Oxford University Press.

Helvarg, D. and J. Scorse 2019. Why a green climate deal needs more blue. Sea Technology, 4 March. https://sea-technology.com/why-a-green-climate-deal-needs-more-blue

International Monetary Fund 2017. China: Article IV Consultation. Washington, DC: IMF. http://www.imf.org/en/News/Articles/2017/08/15/pr17326-china-imf-executive-board-concludes2017-article-iv-consultation

Johnson, M.T., H. Thomas, N. McDonald, N. Hilmi, E. van Doorn and C. Marandino. 2018. Managing the Ocean's role in $\mathrm{CO}_{2}$ mitigation? EGU General Assembly Conference Abstracts, Proceedings from conference held 4-13 April, 2018 in Vienna, p. 19819. http://adsabs.harvard.edu/abs/2018EGUGA..2019819J

Kangethe, K. 2017. East Africa mega projects reduce by half in 2016: Deloitte Report, Capital Business, 2 February, http://www.capitalfm.co.ke/business/2017/02/east-africa-mega-projects-reduce-half-2016deloitte-report

Kathijotes, N. 2013. Blue economy: environmental and behavioural aspects towards sustainable coastal development. Procedia 101: 7-13. 
Kerr, S., L. Watts, R. Brennan, R. Howell, M. Graziano, A. O'Hagan, D. van der Horst, S. Weir, G. Wright and B. Wynne. 2018. Shaping Blue Growth. In C. Foulds and R. Robison (eds.). Advancing energy policy. London: Palgrave Macmillan. Pp. 31-46.

Klein, N. 2014. This changes everything. Toronto: Alfred A. Knopf.

Lange, A. et al. 2018. The changing wealth of nations 2018. Washington, DC: The World Bank.

Llewellyn, L., S. English and S. Barnwell 2016. A roadmap to a sustainable Indian Ocean Blue Economy. Journal of the Indian Ocean Region 12(1): 52-66.

Martinez-Alier, J. 2002. The environmentalism of the poor. Cheltenham: Edward Elgar.

Masie, D. and P. Bond 2018. Eco-capitalist crises in the Blue Economy: Operation Phakisa's small, slow failures. In V. Satgar (ed.). The climate crisis: South African and global democratic eco-socialist alternatives. Johannesburg: Wits University Press.

Mchunu, W. 2016. Foreign investment will unlock KZN's potential. The Mercury (Durban), 12 November.

McKinsey Globalization Institute. 2019. Globalization in transition. New York: McKinsey.

Naidoo, O. 2012. Tourism focus can win city investment. The Mercury, 8 February, http://www.iol.co.za/mercury/tourism-focus-can-win-city-investment1.1229658?ot=inmsa.ArticlePrintPageLayout.ot

National Planning Commission 2012. National Development Plan: vision for 2030. Pretoria: National Planning Commission.

National Union of Metalworkers of South Africa. 2015. Electricity Crisis Conference Declaration, Johannesburg, 5 June. http://www.polity.org.za/article/numsa-electricity-crisis-conference-declaration2015-06-05

Oceans not Oil. 2018. Website. Durban. https://oceansnotoil.com/

Operation Phakisa 2017. Offshore oil and gas exploration. Pretoria. https://www.operationphakisa.gov.za/operations/oel/oilGas/Pages/default.aspx

Paton, C. 2014. Transnet's Durban port plan earns 'climate-change denialist' gibe, Business Day, 20 January, http://www.bdlive.co.za/business/transport/2014/01/20/transnets-durban-port-plan-earns-climatechange-denialist-gibe

Pauli, G. 2010. The Blue Economy. Taos: Paradigm Publishers.

Pieterse, D., T. Farole, M. Odendaal and A. Steenkamp. 2016. Supporting export competitiveness through port and rail network reforms. Policy Research Working Paper 7532. Washington, DC: World Bank Trade and Competitiveness Global Practice Group.

Radebe, J. 2018. Integrated Resource Plan. Pretoria: Republic of South Africa Department of Energy.

Reuters. 2019. More Than 50 Dead in South Africa after heavy rains. New York Times, 24 April. https://www.nytimes.com/reuters/2019/04/24/world/africa/24reuters-safricaflooding.html?partner=IFTTT

Republic of South Africa. 2014. Unlocking the Economic potential of South Africa's oceans: marine protection services and governance executive summary. Operation Phakisa, 15 August. http://tinyurl.com/y8vpfkpj

Republic of South Africa 2017. National Climate Change Adaptation Strategy. Pretoria, Department of Environmental Affairs.

SA Info 2006. SA claims vast tracts of sea floor. Brand South Africa, 20 June. https://www.brandsouthafrica.com/south-africa-fast-facts/news-facts/maritime-claims-200605

Sakhuja, V. 2015. Harnessing the Blue Economy. Indian Foreign Affairs Journal 10(1): 39-49.

Satgar, V. (ed.). The climate crisis: South African and global democratic eco-socialist alternatives. Johannesburg: Wits University Press. 
Shepard, W. 2017. These 8 companies are bringing the 'New Silk Road' to life, Forbes, 12 March, https://www.forbes.com/sites/wadeshepard/2017/03/12/8-new-silk-road-companies-that-you-caninvest-in

Smith-Godfrey, S. 2016. Defining the Blue Economy. Maritime Affairs 12(1): 58-64.

South Durban Community Environmental Alliance. 2008. Spatial and development vision for the people of South Durban. Durban: SDCEA.

South Durban Community Environmental Alliance. 2011. Feeling the heat in Durban. Capitalism Nature Socialism 22(4): 50-73.

Spalding, M. 2016. The new Blue Economy. Journal of Ocean and Coastal Economics 2(2).

Thompson, L., P. Tsolekile de Wet and F. Awaseh. 2018. Community development, BRICS international development assistance and the lessons of Coega. ACCEDE Working Paper 17. Cape Town: University of the Western Cape.

Total Oil Company 2019. Total makes significant discovery and opens new petroleum province offshore South Africa. Press release, Paris, 7 February. https://www.total.com/en/media/news/press-releases/totalmakes-significant-discovery-and-opens-new-petroleum-province-offshore-south-africa

United Nations 2012. Concept paper on the Blue Economy. New York: United Nations. https://sustainabledevelopment.un.org/content/documents/2978BEconcept.pdf

United Nations Conference on Trade and Development. 2017. World Investment Report 2017. Geneva: UNCTAD.

United Nations Conference on Trade and Development. 2018. World Investment Report 2018. Geneva: UNCTAD.

van Wyk, J. 2015. Defining the Blue Economy as a South African strategic priority. Journal of the Indian Ocean Region 11(2): 153-169.

Wagner, L. 2018. Sustainable Blue Economy Conference concludes with 62 commitments. International Institute for Sustainable Development, London, 4 December. https://sdg.iisd.org/news/sustainable-blueeconomy-conference-concludes-with-62-commitments/

Washinyira, T. 2016. We will die for our land, say angry Xolobeni villagers as dune mining looms, Amabhungane, Johannesburg, 12 February, http://amabhungane.co.za/article/2016-02-12-we-will-diefor-our-land-say-angry-xolobeni-villagers-as-dune-mining-looms

Wasserman, H. 2019. This MTN boss could make billions from the massive Brulpadda gas find - and e.tv's owner could also benefit, Business Insider, 12 February. https://www.businessinsider.co.za/mtn-bossstake-in-brulpadda-gas-find-2019-2

Winder, G. and R. Le Heron. 2017. Assembling a Blue Economy moment? Dialogues in Human Geography 7(1): 3-26.

World Bank. 2014. Little green data book. Washington: The World Bank.

World Bank. 2018a. Toward a Blue Economy: a pathway for sustainable growth in Bangladesh. Washington DC: World Bank South Asia Region.

World Bank 2018b. World Bank data catalogue. Washington, DC: World Bank Group.

World Forum of Fisher Peoples and the World Forum of Fish Harvesters and Fish Workers. 2017. Statement on the SDGs and the UN's Ocean Conference. New York, 4 June. http://worldfishers.org/wpcontent/uploads/2017/06/WFF.WFFP_.statement.NYOC_.June_.2017.pdf

Xin Zhang 2016. Chinese capitalism and the New Silk Roads. Aspen Review 4. https://www.aspenreview.com/article/2017/chinese-capitalism-and-the-new-silk-roads/

Zuma, J. 2014. Address by the President at the Launch of Operation Phakisa Big Fast Results Implementation Methodology, Durban. http://www.gov.za/address-president-jacob-zuma-launch-operation-phakisabig-fast-results-implementation-methodology 